\title{
Correction to: Multivariate data analysis of capacitance frequency scanning for online monitoring of viable cell concentrations in small-scale bioreactors
}

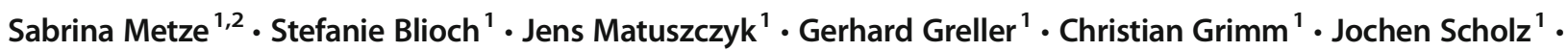 \\ Marek Hoehse ${ }^{1}$
}

Published online: 13 July 2021

(C) Springer-Verlag GmbH Germany, part of Springer Nature 2021

Correction to: Analytical and Bioanalytical Chemistry (2020) 412:2089-2102

https://doi.org/10.1007/s00216-019-02096-3

The article Multivariate data analysis of capacitance frequency scanning for online monitoring of viable cell concentrations in small-scale bioreactors, written by Sabrina Metze, Stefanie Blioch, Jens Matuszczyk, Gerhard Greller, Christian Grimm, Jochen Scholz and Marek Hoehse, was originally published Online First without Open Access. After publication in volume 412, issue 9, page 2089-2102, the author decided to opt for Open Choice and to make the article an Open Access publication. Therefore, the copyright of the article has been changed to (OThe Author(s) 2021 and the article is forthwith distributed under the terms of the Creative Commons Attribution 4.0 International License, which permits use, sharing, adaptation, distribution and reproduction in any medium or format, as long as you give appropriate credit to the original author(s) and the source, provide a link to the Creative
Commons licence, and indicate if changes were made. The images or other third party material in this article are included in the article's Creative Commons licence, unless indicated otherwise in a credit line to the material. If material is not included in the article's Creative Commons licence and your intended use is not permitted by statutory regulation or exceeds the permitted use, you will need to obtain permission directly from the copyright holder. To view a copy of this licence, visit http://creativecommons.org/licenses/by/4.0.

Publisher's note Springer Nature remains neutral with regard to jurisdictional claims in published maps and institutional affiliations.

The online version of the original article can be found at https://oi.org/ 10.1007/s00216-019-02096-3

Marek Hoehse

Marek.Hoehse@sartorius.com

1 Sartorius Stedim Biotech GmbH, August-Spindler-Str. 11, 37079 Göttingen, Germany

2 Leibniz University of Hannover, Welfengarten 1, 30161 Hannover, Germany 